\title{
MODEL PEMBELAJARAN KONSTRUKTIVISME DALAM PEMBELAJARAN MATEMATIKA TEKNIK
}

\author{
Azmil Azman, Nizwardi Jalinus, Ambiyar, Giatman \\ Fakultas Teknik Universitas Ekasakti, Fakultas Teknik Universitas Negeri padang \\ Email: azmilazman@unespadang.ac.id; nizwardi@unp.ac.id; ambiyar@ft.unp.ac.id; giatman@ft.unp.ac.id
}

\begin{abstract}
The purpose of this study is to reveal the effectiveness of the learning model used in learning mathematics techniques. In this study, the authors apply the quasi-experimental method with the chosen research design is treatment by block. Data is collected by providing diagnostic tests and formal reasoning tests and analyzed using ANAVA and t-tests. The results of data analysis show that: (1) Mathematical misconceptions of students who take constructivism learning are lower than Mathematics misconceptions of students who take conventional learning; (2) Mathematical misconceptions of students who have high formal reasoning who follow constructivism learning are lower than Mathematical misconceptions of students who have high formal reasoning who follow conventional learning; (3) Mathematical misconceptions of students who have low formal reasoning who follow constructivism learning are lower than Mathematical misconceptions of students who have low formal reasoning who follow conventional learning; (4) There is no interaction between the learning model with the student's formal reasoning towards students' misconceptions in engineering mathematics subjects. Based on the results of this study, it can be concluded that the constructivist learning model is suitable to be applied in learning mathematics techniques.
\end{abstract}

Keywords: constructivism, learning, student, Lecturer

\section{Abstrak}

Tujuan Penelitian ini untuk mengungkapkan keefektifan model pembelajaran yang digunakan dalam pembelajaran matematika teknik. Dalam penelitian ini, penulis menerapkan metode quasi eksperimen dengan desain penelitian yang dipilih adalah treatment by block. Populasi penelitian ini adalah mahasiswa program studi teknik mesin universitas ekasakti Padang, dari dua kelas yang dipilih secara acak dengan menggunakan teknik cluster random sampling. Data dikumpulkan dengan cara memberikan tes diagnostik dan tes penalaran formal dan dianalisis dengan menggunakan Anava dan t-tes. Hasil analisis data menunjukkan bahwa : (1) Miskonsepsi Matematika mahasiswa yang mengikuti pembelajaran konstruktivisme lebih rendah dari miskonsepsi Matematika mahasiswa yang mengikuti pembelajaran konvensional; (2) Miskonsepsi Matematika mahasiswa yang memiliki penalaran formal tinggi yang mengikuti pembelajaran konstruktivisme lebih rendah dari miskonsepsi Matematika mahasiswa yang memiliki penalaran formal tinggi yang mengikuti pembelajaran konvensional; (3) Miskonsepsi Matematika mahasiswa yang memiliki penalaran formal rendah yang mengikuti pembelajaran konstruktivisme lebih rendah dari miskonsepsi Matematika mahasiswa yang memiliki penalaran formal rendah yang mengikuti pembelajaran konvensional; (4) Tidak terdapat interaksi antara model pembelajaran dengan penalaran formal mahasiswa terhadap miskonsepsi mahasiswa pada mata pelajaran matematika teknik. Berdasarkan hasil penelitian ini, dapat disimpulkan bahwa model pembelajaran konstruktivisme cocok diterapkan dalam pembelajaran matematika teknik.

Kata kunci: konstruktivisme, pembelajaran, mahasiswa, dosen

\section{1. pendahuluan}

Matematika dikenal dengan ilmu pengetahuan yang abstrak. Karakter utama pembelajaran Matematika ini merupakan disiplin serta pola pikir yang logis, kritis, sistematis serta konsisten, dan menuntut daya kreatif serta inovatif. pada konsep-konsep Matematika mulai dari yang sederhana sampai ke yang lebih lanjut, pola pikir itu diikuti serta dianut secara ketat sekali. Pola pikir ini bisa dipelajari dan dihayati menggunakan mempelajari Matematika dari cara yang benar. Hal ini dilakukan supaya pemahaman peserta didik terhadap konsep Matematika yang abstrak tadi tidak keliru atau tidak terjadi miskonsepsi.

Miskonsepsi ialah faktor yang menghambat peserta didik untuk buat membentuk sendiri ilmunya secara benar [7]. Miskonsepsi bukan semata-mata berarti tidak adanya pengetahuan dalam diri peserta didik 
[17]. mampu terjadi pada waktu peserta didik menyusun pengetahuannya, dia mengaitkannya menggunakan pengalaman yang tak lengkap atau tidak relatif atau sebab penjelasan yang keliru atau penjelasan dipersepsinya keliru. menggunakan adanya miskosepsi itu kentara bahwa pengetahuan sungguh merupakan bentukan peserta didik sendiri atau bukan sintesis guru [10].

Hal terpenting pada teori konstruktivisme bahwa dalam proses pembelajaran peserta didik wajib menekankan dan aktif pada pengembangan pengetahuan mereka, bukan guru. penekanan aktif ini pada pembelajaran peserta didik harus dikembangkan. Kreativitas serta kegiatan peserta didik akan membantu mereka tetap mampu pada kehidupan kognitif mereka [9].

Pembelajaran lebih ditujukan pada pembelajaran eksperimental, yang adalah adaptasi asal humanisme sesuai pengalaman konkret di laboratorium, diskusi dengan rekan kerja, yang kemudian direnungkan dan diubah menjadi gagasan serta pengembangan konsep baru. oleh karena itu, keberadaan pendidikan dan pedagogi tidak berpusat pada pendidik tetapi pada peserta didik. pedagogi yang berpusat pada peserta didik menekankan pada pemecahan duduk perkara yang kreatif serta keterampilan berpikir kritis [4]. Belajar mirip ini selain berurusan dengan yang akan terjadi (outcome) juga memperhatikan proses dalam konteks eksklusif.

Teori konstruktivis mempunyai implikasi terhadap pembelajaran matematika [1]. Pembelajaran dapat matematika membantu peserta didik membuatkan konsep matematika menggunakan kemampuan mereka sendiri lewat proses internalisasi sebagai akibatnya konsep tersebut direkonstruksi dengan mengganti berita menjadi konsep baru. dapat dikatakan bahwa belajar matematika artinya membentuk pemahaman. Pemahaman atau pengetahuan dapat dibangun oleh peserta didik sendiri sesuai pengetahuan sebelumnya.

Kesalahpahaman tadi bisa diartikan menjadi konsep yang tidak sesuai dengan pemahaman ilmiah atau pemahaman yang diterima sang para ilmuwan. Kesalahpahaman sebagai interpretasi konsep pada pernyataan yang tidak bisa diterima [6]. Kesalahpahaman menjadi pandangan baru yang tidak akurat, kesalahpahaman, pembagian terstruktur mengenai model yang galat, kekacauan dalam konsep yang tidak selaras dan korelasi hierarkis asal konsep yang salah [9]. Kesalahpahaman bisa terjadi pada seluruh tingkat pendidikan, asal SD sampai universitas.

Pada pembelajaran matematika, miskonsepsi dapat terjadi atau dijumpai pada beberapa sumber, diantaranya : makna istilah, aspek simpel, simplifikasi, dan ketunggalan struktur matematika [13]. Bila seseorang guru tidak memahami struktur matematika, akan mengakibatkan guru mengalami miskonsepsi (kesalahan konsep) yang diajarkan pada peserta didik [16].

\section{Metode}

Populasi penelitian ini antara lain peserta didik semester 3 Fakultas Teknik Universitas Ekasakti Padang. Jumlah peserta didik semester tiga yang mengambil mata kuliah Matematika artinya 322 orang, yang tersebar di delapan kelas. Jumlah peserta didik setiap kelas homogen-homogen 40 orang peserta didik. Penempatan peserta didik setiap kelas tidak berdasarkan di kriteria-kriteria eksklusif, hanya didasarkan di angka urut pendaftaran ulang pada waktu masuk pada Universitas Ekasakti. Penelitian dilakukan pada semester gasal tahun ajaran 2019/2020

Teknik pengambilan sampel yang digunakan ialah cluster secara acak sampling dimana populasi diacak berdasarkan grup (kelas) serta kemudian dipilih 2 kelas sebagai kelas eksperimen dan kelas kontrol. Kelas yang terpilih menjadi kelas eksperimen merupakan kelas A serta sebagai kelas kontrol adalah kelas B.

Metode penelitian yang dipilih artinya eksperimen semu atau quasi eksperimen. ialah, kontrol dari variabel yang diteliti tidak bisa dilakukan seketat dalam penelitian sains yang sempurna. Desain penelitian yang dipilih artinya treatment by blok. Faktor pembagian terstruktur mengenai adalah variabel pemoderasi berasal dari penalaran formal siswa. Pemilahan di bagi menjadi 2 tingkatan: penalaran secara formal diatas rata-rata grup (27\% dari atas) dan dibawah rata-rata gerombolan (27\% dari bawah) setelah itu data disusun mulai dari tertinggi ke terendah. penjabaran ini diharapkan dapat meningkatkan ketepatan akibat penelitian ini. pada melakukan penelitian ini, pemisahan taraf penalaran formal peserta didik adalah makna pseudo pada aktivitas eksperimen, peserta didik tidak terpisah secara signifikan dalam perlakuan penerapan contoh pembelajaran antara grup yang mempunyai taraf penalaran formal. buat pada atas serta di bawah rata-rata.

Tabel 2. Desain treatment by block

\begin{tabular}{|l|r|c|}
$\begin{array}{r}\text { Model } \\
\text { pembelajaran } \\
(\mathrm{A})\end{array}$ & $\begin{array}{c}\text { Konstruktivisme } \\
\left(\mathrm{A}_{1}\right)\end{array}$ & $\begin{array}{c}\text { Konvensio } \\
\text { nal } \\
\left(\mathrm{A}_{2}\right)\end{array}$ \\
$\begin{array}{l}\text { Penalaran } \\
\text { formal ( } \mathrm{B})\end{array}$ & & \\
\hline Penalaran Tinggi $\left(\mathrm{B}_{1}\right)$ & $\mathrm{A}_{1} \mathrm{~B}_{1}$ & $\mathrm{~A}_{2} \mathrm{~B}_{1}$ \\
\hline Penalaran rendah $\left(\mathrm{B}_{2}\right)$ & $\mathrm{A}_{1} \mathrm{~B}_{2}$ & $\mathrm{~A}_{2} \mathrm{~B}_{2}$ \\
\hline
\end{tabular}


Keterangan :

$\mathrm{A}_{1} \mathrm{~B}_{1}=$ Kelompok mahasiswa yang menerima model pembelajaran konstruktivis untuk alasan formal yang tinggi

$\mathrm{A}_{1} \mathrm{~B}_{2}=$ Kelompok mahasiswa yang menerima model pembelajaran konstruktivisme untuk penalaran formal rendah

$\mathrm{A}_{2} \mathrm{~B}_{1}=$ Kelompok mahasiswa yang menerima model pembelajaran konvensional untuk penalaran formal tinggi

$\mathrm{A}_{2} \mathrm{~B}_{2}=$ Kelompok mahasiswa yang menerima model pembelajaran konvensional untuk penalaran formal rendah.

Tabel 1. menggambarkan bahwa penelitian ini menyampaikan perlakuan pembelajaran dengan 2 contoh, yaitu konstruktivisme buat kelas eksperimen dan konvensional untuk kelas kontrol, yang akan memberikan bagaimana kesalahpahaman peserta didik bisa dikurangi dalam pembelajaran matematika sehabis menerima Perlakuan.

Penelitian eksperiment ini meliputi beberapa variabel dan bisa dibagi menjadi beberapa kelompok sebagai berikut. (Y) Variabel terikat, variabel dependen dalam penelitian ini adalah miskonsepsi peserta didik. (X) Variabel bebas, variabel bebas dipenelitian ini, adalah model pembelajaran yang terdiri atas: (1) model pembelajaran konstruktivis yang diterapkan pada grup eksperimen dan (2) model pembelajaran konvensional di grup kontrol. Variabel moderasi pada penelitian ini merupakan penalaran formal peserta didik. Penggunaan penalaran formal menjadi variabel moderasi bertujuan buat menganalisis impak sederhana asal model pembelajaran konstruktivisme di setiap lapisan penalaran formal, dan ada atau tidak adanya interaksi antara penalaran formal dan model pembelajaran.

Penelitian eksperimen ini melibatkan beberapa variabel yang bisa dikelompokkan sebagai berikut. Variabel Terikat (Y), Variabel terikat pada penelitian ini ialah miskonsepsi anak didik. Variabel Bebas (X), Variabel bebas dalam penelitian ini ialah contoh pembelajaran yang terdiri berasal : (1) model pembelajaran konstruktivisme yang dikenakan di grup eksperimen, dan (2) contoh pembelajaran konvensional pada gerombolan kontrol. Variabel Moderator pada penelitian ini adalah penalaran formal anak didik. Penggunaan penalaran formal menjadi variabel moderator dimaksudkan buat menganalisis impak lugas (simple effect) contoh belajar konstruktivisme terhadap masing-masing penalaran formal dan terdapat tidaknya interaksi antara penalaran formal serta model pembelajaran.
Teknik pengumpulan data

Sesudah instrumen diuji serta memperoleh item tes diagnostik serta penalaran formal yang baik, ke 2 instrumen digunakan buat mengumpulkan data penelitian, yaitu data tentang kesalahpahaman matematika dan penalaran formal untuk peserta. buat menerima deskripsi peserta didik menggunakan latar belakang formal tinggi dan rendah pada kelas eksperimen serta kontrol, peneliti melakukan tes penalaran formal pada peserta didik sebelum perlakuan diterapkan.

Waktu yang tersedia buat menuntaskan tes penalaran formal ini dibatasi hingga $40 \mathrm{mnt}$ buat 21 pertanyaan. berdasarkan hasil kualifikasi, peserta didik diklasifikasikan menjadi peserta didik tingkat tinggi, yaitu penalaran formal diatas rata- rata grup ( $27 \%$ dari atas) serta peserta didik dengan penalaran formal rendah, mis. Penalaran formal pada bawah rata- rata kelompok (27\% dari bawah) setelah data diurutkan dari yang terbesar ke yang terkecil.

Tes diagnostik didistribusikan kepada peserta didik setelah mengkaji PLSV ( persamaan linear satu variabel) dan PtLSV ( pertidaksamaan linear satu variabel). buat distribusi tes diagnostik pada peserta didik, para peneliti sendiri yang melakukannya. waktu yang diizinkan bagi peserta didik untuk menyelesaikan ujian adalah tiga jam (120 mnt) dengan total 30 pertanyaan ujian. Selama tes, para peneliti memantau semua peserta didik buat menghindari kecurangan. Dari hasil tes diagnostik diketahui peserta didik yang tahu konsep, peserta didik yang memiliki kesalahpahaman, peserta didik yang tidak memiliki pengetahuan serta peserta didik yang hanya menebak jawaban. namun, data yang dianalisis pada penelitian ini hanya kesalahpahaman peserta didik.

Tes normalitas dilakukan di data asal kesalahpahaman peserta didik yang mengikuti pembelajaran menggunakan model pembelajaran konstruktivis dan model pembelajaran konvensional. Tes normalitas data dilakukan menggunakan SPSS versi 16.

Terdapat enam set data yang diuji buat memilih normalitas, yaitu: (1) data tentang kesalahpahaman peserta didik sesudah belajar konstruktivisme, (2) data tentang kesalahpahaman pesertadidik yang memiliki alasan formal tinggi serta yang peserta didik mengikuti pembelajaran konstruktivisme, (3) data tentang kesalahpahaman peserta didik yang mempunyai penalaran formal rendah dan mengikuti pembelajaran konstruktivisme, (4) datatentang kesalahpahaman peserta didik yang mengikuti pembelajaran konvensional, (5) data tentang kesalahpahaman peserta didik yang mempunyai penalaran formal tinggi dan mengikuti pembelajaran konvensional serta (6) 
data tentang kesalahpahaman peserta didik yang mempunyai penalaran formal rendah serta mengikuti pembelajaran konvensional.

\section{Hasil dan Pembahasan}

Perbedaan miskonsepsi Matematika pesertadidik yang mengikuti model pembelajaran konstruktivisme serta konvensional. Uji t dengan SPSS versi 16 menawarkan nilai t sebesar $-2,641$ dengan probabilitas 0,012 . Nilai probabilitas ini lebih sedikit jika dibandingkan dengan derajat kepercayaan $\alpha=0,05$. Jadi Ho ditolak dan $\mathrm{H} 1$ diterima. Ini artinya pesertadidik yang mengikuti pembelajaran konstruktivisme mengalami miskonsepsi yang lebih rendah bila dibanding dengan pesertadidik yang mengikuti pembelajaran konvensional.

Perbedaan miskonsepsi Matematika peserta didik berpenalaran formal tinggi dan mengikuti model pembelajaran konstruktivisme serta yang mengikuti pembelajaran konvensional. Uji t menggunakan SPSS versi 16 memperlihatkan nilai $\mathrm{t}$ sebanyak $-2,227$ sedangkan probabilitas 0,038 . Nilai probabilitas ini lebih rendah kalau dibandingkan dengan derajat kepercayaan $\alpha=0,05$. Jadi Ho ditolak lalu H1 diterima. Ini berarti peserta didik berpenalaran formal tinggi yang mengikuti pembelajaran konstruktivisme mengalami kesalahpahaman yang lebih sedikit dibandingkan dengan mereka yang mengikuti pembelajaran konvensional

Perbedaan miskonsepsi Matematika peserta didik berpenalaran formal kecil yang mengikuti model pembelajaran konstruktivisme serta yang mengikuti model pembelajaran konvensional. Uji t menggunakan SPSS versi 16 memberikan nilai t sebesar $-2,689$ menggunakan probabilitas 0,014. Nilai probabilitas ini lebih mungil Jika dibandingkan menggunakan derajat kepercayaan $\alpha=0,05$. Jadi Ho ditolak lalu H1 diterima. Ini artinya peserta didik berpenalaran formal rendah yang mengikuti pembelajaran konstruktivisme mengalami kesalahpahaman yang lebih sedikit dibandingkan dengan mereka yang ikut dalam model pembelajaran konvensional.

Interaksi antara model pembelajaran menggunakan penalaran formal dalam mengurangi miskonsepsi peserta didik. hubungan ialah korelasi ketergantungan antara suatu variabel terhadap tingkat eksklusif berasal variabel lain. yang akan terjadi uji hipotesis yang telah dilakukan mengindikasi tidak adanya interaksi diantara model pembelajaran dengan penalaran formal peserta didik dalam mempengaruhi kesalahpahaman peserta didik. yang akan terjadi perhitungan anava memperkuat pertanda tersebut sebab berasal perhitungan anava nampak nilai $F$ hitung $=1,37$ yang ternyata lebih rendah dibandingkan dengan $\mathrm{F}$ tabel=4,08 dengan tingkat signifikannya 0,05 . sebagai akibatnya Ho di terima sedangkan $\mathrm{H} 1$ di tolak. Jadi tidak ada hubungan yang signifikan antara model pembelajaran dengan penalaran formal pada pengaruhnya terhadap miskonsepsi peserta didik.

Sebab terdapat kesesuaian antara karakteristik model pembelajaran konstruktivisme yang mendukung perubahan miskonsepsi , masuk akal Jika pesertadidik yang mengikuti model pembelajaran konstruktivisme mempunyai miskonsepsi yang lebih rendah daripada model belajar konvensional.

Jika dibandingkan antara metode pembelajaran konvensional dengan konstruktivisme, maka pembelajaran konstruktivisme lebih baik dipergunakan untuk mengurangi miskonsepsi peserta didik yang memiliki penalaran formal tinggi. Hal ini dikarenakan pesertadidik lebih aktif pada proses pembelajaran, apalagi ditunjang menggunakan eksperimen serta penggunaan Lomba Kompetensi peserta didik yang bisa membantu peserta didik lebih aktif serta lebih mudah dalam mengingat konsep-konsep yang diberikan.

Bila dibandingkan antara metode pembelajaran konvensional menggunakan konstruktivisme, maka menggunakan diberikannya peserta didik lebih banyak kesempatan dalam mengemukakan pendapat dan gagasan yang mereka miliki serta ditunjang menggunakan eksperimen yang bisa membantu peserta didik lebih aktif serta lebih simpel pada mengingat konsep-konsep yang diberikan, maka pembelajaran konstruktivisme lebih baik dipergunakan buat mengurangi miskonsepsi peserta didik yang mempunyai penalaran formal rendah.

Tidak terjadinya hubungan antara contoh pembelajaran menggunakan penalaran formal peserta didik pada membarui miskonsepsi peserta didik menjadi konsepsi ilmiah dikarenakan secara teori peserta didik berpenalaran formal tinggi permanen lebih unggul Bila dibandingkan menggunakan peserta didik yang berpenalaran formal rendah. tidak adanya hubungan ini juga membagikan bahwa model pembelajaran konstruktivisme secara signifikan telah bisa $\mathrm{m}$ ereduksi miskonsepsi yang ada di struktur kognitif peserta didik. contoh pembelajaran konstruktivisme akan berlaku di seluruh taraf penalaran formal baik penalaran formal tinggi maupun penalaran formal rendah.

\section{Kesimpulan Dan Saran \\ a. Kesimpulan}

Sejalan dengan pertarungan, tujuan penelitian serta yang akan terjadi-hasil penelitian 
yang dikemukakan, maka dapat ditarik kesimpulan sebagai berikut:

- Miskonsepsi Matematika peserta didik yang mengikuti pembelajaran konstruktivisme lebih rendah dari miskonsepsi Matematika peserta didik yang mengikuti pembelajaran konvensional. Ini berarti bahwa pembelajaran konstruktivisme lebih efektif daripada pembelajaran konvensional untuk mengurangi miskonsepsi Matematika peserta didik

- Miskonsepsi Matematika peserta didik yang mempunyai penalaran formal tinggi yang mengikuti pembelajaran konstruktivisme lebih rendah berasal miskonsepsi Matematika peserta didik yang mempunyai penalaran formal tinggi yang mengikuti pembelajaran konvensional. Ini berarti bahwa pembelajaran konstruktivisme lebih efektif daripada pembelajaran konvensional buat mengurangi miskonsepsi Matematika peserta didik yang memiliki penalaran formal tinggi.

- Miskonsepsi Matematika peserta didik yang mempunyai penalaran formal rendah yang mengikuti pembelajaran konstruktivisme lebih rendah dari miskonsepsi Matematika peserta didik yang mempunyai penalaran formal rendah yang mengikuti pembelajaran konvensional. Ini berarti bahwa pembelajaran konstruktivisme lebih efektif daripada pebelajaran konvensional buat mengurangi miskonsepsi Matematika peserta didik yang memiliki penalaran formal rendah.

- tak terdapat hubungan yang signifikan antara model pembelajaran menggunakan penalaran formal peserta didik terhadap miskonsepsi peserta didik pada mata pelajaran Matematika.

Secara umum, dari hasil penelitian ini dapat disimpulkan bahwa pembelajaran konstruktivisme lebih efektif dari pada pembelajaran konvensional buat mengurangi miskonsepsi peserta didik, baik buat peserta didik yang mempunyai penalaran formal tinggi juga bagi peserta didik yang mempunyai penalaran formal rendah.

\section{b. Saran}

berdasarkan yang akan terjadi penelitian terdapat beberapa tips yang diajukan yaitu saran pemanfaatan yang akan terjadi penelitian dan saran buat penelitin lanjutan.

Pertama. dibutuhkan bagi Dosen Matematika dapat menerapkan pembelajaran konstruktivisme yang berasal hasil penelitian ini memberikan dampak yang cukup signifikan dalam mengurangi miskonsi Matematika siswa. kedua diperlukan di peneliti selanjutnya melakukan penelitian dengan skala yang lebih luas sebagai akibatnya hasilnya dapat digeneralisasikan di populasi yang lebih besar. di samping itu konsep yang dibahas juga diperluas sebagai akibatnya bisa diketahui konsep Matematika apa saja yang miskonsepsinya bisa dicegah melalui pembelajaran konstruktivisme.

\section{Daftar Pustaka}

Confrey, J. 1992. "What Constructivism Implies for Teaching". In Journal For Research In Mathematics Education (Ed). Constructivism Views On The Teaching And Learning Of Mathematics. Virginia : National Council of Teachers of Mathematics

Dougiamas, M. 1998. A Journey Into Construktivism.

Hendryadi, H. (2017). Validitas Isi: Tahap Awal Pengembangan Kuesioner. Jurnal Riset Manajemen Dan Bisnis (JRMB) Fakultas Ekonomi UNIAT, 2(2), 169-178. https://doi.org/10.36226/jrmb.v2i2.47

Muhammad Nur dkk. 2000. Pengajaran Berpusat Kepada Siswa dan Pendekatan Konstruktivis dalam pembelajaran. Surabaya Universitas Negeri Padang.

Murphy, E. (1997). Constructivism: From Philosophy to Practice. Journal of Interactive Online Learning .

Novak, J.D dan Bob Gowin. 1984. Learning How to Learn. Cambrige University Press

Nur Asma dkk. 2002. Model Pembelajaran untuk menanggulangi Miskonsepsi Bidang Studi Fisika SMU dalam Rangka Meningkatkan Mutu Pendidik di Sumatera Barat. Laporan Penelitian Padang: FMIPA Universitas Negeri Padang

Olusegun, S. (2015). Constructivism Learning Theory: A Paradigm for Teaching and Learning. IOSR Journal of Research \& Method in Education Ver. I. https://doi.org/10.9790/7388-05616670

Paul Suparno. 1997. Filsafat Kontruktivisme dalam Pendidikan. Jakarta : Garasindo 2005 Miskonsepsi dan Perubahan Konsep dalam Pendidikan Fisika. Jakarta : Grasindo.

Sekaran, U, (2006). Metode Penelitian Bisnis. Jakarta : Salemba Empat 2001. Evaluasi Pendidikan. Jakarta : Bumi Aksara

Soedjadi, R. (2000). Kiat pendidikan matematika di Indonesia: konstatasi keadaan masa kini menuju harapan masa depan. Direktorat Jenderal Pendidikan Tinggi. 
https://doi.org/10.1080/00405000.2015.11 $\underline{33105}$

Sugiyono. 2013. Metode Penelitian Menejemen. Bandung: Alfabeta

Suharsimi, A. (2013). Prosedur Penelitian : Suatu Pendekatan Praktik (Edisi Revisi). Jakarta: Rineka Cipta. https://doi.org/10.1017/CBO97811074153 $\underline{24.004}$
Sumardyono. 2004. Karakteristik Matematika dan Implikasinya terhadap Pembelajaran Matematika. Yogyakarta : Departemen Pendidikan Nasional.

Wartono dkk. 2004. SAIINS. Materi Pelatihan Terintegrasi. Jakarta: Departemen Pendidikan Nasional. 